\title{
Regulation of Private Security Companies and Equitable Policing in Nigeria
}

\author{
Plangshak Musa Suchi ${ }^{a}$
}

\begin{abstract}
Private security companies through the services they provide complement the police in crime prevention, order maintenance, and general improvement of security in societies thereby contributing to sustainable national development. In order to fully benefit from their contribution and prevent them from engaging in illegal activities, states formulate and enforce policies that seek to regulate their activities. This paper examines the regulation of private guards companies in Nigeria using Abuja as its empirical core. The main aim is to promote understanding of how the private security industry is regulated and evaluate the effectiveness of the existing regulatory policy. Data for the paper were generated from in-depth interviews with the NSCDC (Nigeria Security and Civil Defence Corps), analysis of the policy for PSCs (private security companies), and a review of the annual performance report of the regulatory agency. The results revealed that the current system of PSC regulation is characterized by a lack of specialty classification of private security licences, limited regulatory scope with a focus on licensing of companies, lack of uniform standards on training, and high cost/difficulties in obtaining operational license. The paper concludes that the current regulatory setup for PSCs in Nigeria is ineffective and unsustainable and recommends an urgent review of the legal framework to alien its provisions with global standards and practices in the private security industry.
\end{abstract}

\section{keywords}

Private security, equitable policing, regulatory policy, sustainable development

The role of private security companies (PSCs) in security provision and sustainable development is increasingly gaining recognition and acceptance in many countries. This is further propelled by the perceived or real increase in insecurity due to an upsurge of insurgency across the globe. PSCs through the wide range of services they provide (such as guard and patrol, security consultancy, training, and capacity development) not only contribute to the activity of making societies safe but also to national development (Bearpark and Schulz 2007; Gumedze 2007).

To the extent that "peace and security" is at the base of the drive to sustainable development (Molomo
2009), and many institutions now share the responsibility for providing security (Johnston and Shearing 2003), it is important to examine the place of PSCs in the matter, particularly how their involvement in policing is regulated. In so doing, it is important to ask certain questions regarding the regulation of PSCs in Nigeria: What are the policies on regulation of

aBingham University, Karu, Nigeria

\section{Correspondent Author:}

Plangshak Musa Suchi, Department of Sociology, Faculty of Humanities, Social and Management Sciences, Bingham University, PMB 005 Kodape, Karu, Nasarawa State, Nigeria 
PSCs in Nigeria? How similar or different are the policies to what obtains in other countries that may be doing better? What is the role and performance of the regulatory authority for PSCs in Nigeria? What measures should the government take to improve the contributions of PSCs to security and sustainable national development?

In providing answers to these questions, the next section appropriately conceptualizes private security and equitable policing, while the third section elaborates on the main concern-Which is the regulation of PSCs in Nigeria. In the fourth section, the author reviews the theories on the role and relationship between private and public policing types and provides a theoretical frame of reference for the paper. The fifth section (and its sub-sections) basically analyzes the regulation of PSCs in Nigeria and how it is characterized while the final section presents the summary, conclusions, and recommendations of the paper.

\section{CONCEPTUALIZING PRIVATE SECURITY AND EQUITABLE POLICING}

Private security as employed here refers to all security related services (such as guard and patrol, security consultancy, security training, and capacity development) provided by registered private companies to individuals, corporate bodies, and the government with a view to improving citizen security. Citizen security according to the World Development Report (The World Bank 2011) includes both "freedom from physical violence and freedom from fear of violence" which applies to "the lives of all members of a society (whether nationals of the country or otherwise)", in all ramification of their "interactions with the state and other members of society” (The World Bank 2011: 16).

This conceptualization of private security is limited to PSCs offering security services to the domestic market. It does not include proprietary (in-house) security or those self-employed individuals that provide security service to the entities that employed them or for themselves (Schmalleger 2009). It also excludes international PSCs with headquarters or offices in several countries which usually offer what the industry refers to as "premium" security services, as well as private military companies (PMCs) offering support services to the armed forces of either their own or a foreign country (Bearpark and Schulz 2007).

The focus on citizen security is based on a recognition of the current shift in understanding of security from security as defence of the state to a focus on human security which places people at the centre of efforts to prevent and recover from violence (Jung 2009; Bassey and Dokubo 2011; The World Bank 2011). Broadly, security as Odekunle (2010: 79) observed, is "the protection of human existence in all its ramifications". However, the term is specifically employed here to refer to a whole range of technologies and practices provided to guarantee the safety of lives and property of members of society, not only by public bodies such as the police or local authorities, but also by PSCs competing in the marketplace.

From the above conception of security and private security in particular, it is easy to understand that PSCs are also involved in policing. For, policing is simply the activity of making societies safe. It involves the preservation of the social order from anything that threatens to disrupt it. Although there are different conceptions (such as consensus versus conflict models) of the social order that policing purported to maintain and sustain (Shearing 1992; Marenin 1985; Alemika 1993), the term is specifically employed here to refer to all purposive activities of both public and private bodies, state and non-state actors, sometimes involving the use of coercion, directed at regulating social behaviour, maintaining order, preventing crime, responding to crime, and restoring order within a social milieu. Such an activity 
is equitable if it addressed the security needs of all members of society regardless of differences in class, gender, age, ethnicity, and religion. The beauty of this definition is that it recognizes that policing "is a broader activity than simply what the police do" (Baker 2002: 29). It also suggests that any security policy that will promote sustainable development must include a policy on regulation of non-state policing bodies such as PSCs.

\section{THE MAIN CONCERN ABOUT PRIVATE SECURITY COMPANIES}

Although private security is not a new phenomenon, there is something new about modern private security, which is its pervasiveness and scope of operation which now extends to emerging public spaces (Shearing and Stenning 1981; Berg 2010). PSCs have also gone global and operate across borders with greatly varying levels of service, governance, and professionalism (Lalonde 2010; Owusu et al. 2016).

In Africa, scholars have drawn attention to the rapid growth currently being experienced in the private security industry and its potential of becoming a major part of a country's local economy (Abrahamsen and Williams 2005; 2009; Gumedze 2007; Lalonde 2010; Owusu et al. 2016). However, there are concerns about the implications of PSCs for policing especially since security is largely regarded by citizens as a public good to be provided by the state. These concerns stem from the perception that the proliferation of the PSCs suggests an increase in insecurity and crimes, as well as a weak state capacity or a deficit in governance and security provision by the state (Isima 2007; Kwaja 2011). The situation in Nigeria is compounded by the fact that the police is perceived as ineffective in preventing and controlling crimes (Alemika and Chukwuma 2004; Chukwuma 2005).

The main concern about PSCs has centred largely on how to regulate their activities to prevent them from engaging in illegal or criminal behaviours and promote professionalism in the industry as well as prevent PSCs from further damaging social cohesion by becoming a commodity that only the wealthy can afford (Gumedze 2007; Bearpark and Schulz 2007). It also has to do with the involvement of PSCs with complex political struggles and the division of authority between them and public security forces as expressed in a report from the Department of International Politics at the University of Wales (Abrahamsen and Williams 2005). Thus, the real concern here is not so much about whether PSCs should be allowed to operate as about how they should act along with the state to provide effective and accountable security for the entire citizenry.

\section{RELATIONSHIP BETWEEN PRIVATE AND PUBLIC POLICING}

Private security guards often act as private police, separate from the public police, providing aspects of police service. Although their role is complementary and closely related to that of the police, there are important differences between the two. While the public police, for example, serves the public at large and is primarily concerned with enforcing the laws, PSCs operate on behalf of private interests and owe their allegiance to clients and employees (Strom et al. 2010). The public police is largely reactive, while the private police is by nature preventative, future oriented, and focused on risk mitigation (Johnston and Shearing 2003).

State-centric conception of policing as ultimately dependent on the use and monopoly of force by the state did not give room for the operation of PSCs, much less their relationship with the public police because of the perception that private security personnel were acting for private interest that was often at odds with the public interest (Shearing 1992). This view (dominant in the 1950s and 1960s) however has come under attack by the laissez-faire conception 
which argues that private policing was an important contemporary phenomenon that needed to be recognized and understood (Kakalik and Wildhorn 1972; Cunningham and Taylor 1985).

Kakalik and Wildhorn (1972), for example, argued that private policing especially contract security, was an "industry" providing a "service" and private police personnel were inoffensive people employed in simple preventive activities necessary for self-defence that the public police had neither the resources nor the inclination to undertake (Kakalik and Wildhorn 1972: 19). Cunningham and Taylor (1985) supported and extended this view by shifting the focus of attention from private policing as self-defence and protection to private policing as crime fighting. Based on the claim that private police was undertaking the same tasks as the public police to the same ends, they moved from a junior partner to an equal partner conception of private policing's relationship to public police (Shearing 1992).

Cunningham and Taylor (1985) went further by using Shearing and Stenning's (1981) criticism of the "vacuum theory" which says private policing was a makeshift response to inadequate state response to keeping the peace to assert that private policing was not a result of the underfunding of the public police. Instead, there was a positive correlation between the growth of private security and "shifts in property relationships" (Shearing and Stenning 1981). Shifts in property relationships towards large geographically connected holdings of mass private property brought about the shift towards private policing initiatives. This re-conception of the relationship between private and public police was in turn employed to argue for a policy of enhanced public-private police cooperation that would accelerate the process of privatization that RAND (i.e. the organisation for which Kakalik and Wildhorn worked) had reported and legitimized. In addition to greater use of private policing in crime fighting, Hallcrest (the organization for which Cunningham and Taylor worked) recommended increased information sharing and interchange of personnel and experience between private and public police (Cunningham and Taylor 1985).

This view fits perfectly with the functionalist perspective in sociology as developed by Talcott Parsons, Emile Durkheim, Robert Merton, Kingsley Davis, Wilbert Moore, and others (Ritzer 1996; 2005). From the perspective they offer, both private and public police are part of the network of actors involved in security provision by the society. Their roles are not only interrelated and interconnected but they interdepend on each other in the course of their function performance. PSCs are partners with the police in the business of keeping the peace. This peace includes the protection of corporate property and the protection of corporate customers and staff. Furthermore, because of the interdependency of security networks, governments are liberalizing the market through deregulation policies which have opened up the way for PSCs to flourish. PSCs are increasingly being regarded as an important component of the agencies that are involved in crime fighting in Nigeria.

As partners in crime fighting, one will expect public and private policing institutions to cooperate and operate in a state of mutual interdependence based on the understanding that their functions are interrelated and interconnected. This will galvanize in realizing the "state of equilibrium" required, or recording a high degree of success in the fight against crime and insecurity. Private and public police should utilize their respective talents and resources in a complementary and coordinated attack on crime to maximize the protection of communities (Cunningham and Taylor 1985). The state has a vital role to play in "steering" both public and private policing bodies to ensure their professionalism (Osborne and Gaebler 1992). This can be achieved by formulating and implementing sustainable policies that regulate their activities. By steering policing, the state is basically "governing by setting the course, 
monitoring direction and correcting deviations from the course set" (Crawford 2006: 453), while leaving the "rowing" to others including the PSCs.

\section{METHOD AND DATA SOURCES}

This paper is part of a doctoral thesis by the author on private security companies and policing in Abuja. The study employed cross-sectional survey research designed that combines both quantitative and qualitative methods of data collection. In particular, the paper relies heavily on the qualitative data generated from in-depth interviews with staff of the private guard companies, department of the NSCDC (Nigeria Security and Civil Defence Corps) at both the headquarters and the Federal Capital Territory (FCT) command. The primary data were complemented by a content analysis of the relevant policy documents on PGCs (private guard companies) in Nigeria (including the PGCs Act of 1986, NSCDC Act 2003, and the amendment of 2007), and the annual performance report of the NSCDC as well as a critical review of the state of the art on regulation of PSCs.

\section{REGULATION OF PRIVATE GUARDS COMPANIES IN NIGERIA}

In this section, the author analyzes how the Nigerian state regulates PGCs and critically discusses the adequacy of the system of regulation. According to Scott (2001):

We can think of regulation as any process or set of processes by which norms are established, the behaviour of those subject to the norms monitored or fed back into the regime, and for which there are mechanisms for holding the behaviour or regulated actors within the acceptable limits of the regime (whether by enforcement action or by some other mechanism). (cited in Gill 2002: 527)

Regulation of PGCs entails putting in place some systems of control and accountability to ensure that private security guards or the companies they work for do not themselves engage in criminal acts (Berg and Nouveau 2011). It is also about having a policy that will ensure the PSCs operate professionally and do not worsen social cohesion by becoming a commodity that only the rich can afford.

Apart from state regulation and oversight of the private security industry, "disciplinary practices" (Foucault 1988) against PSCs could be initiated by the private security industry itself, i.e. through industry self-regulation or through end-user/client industry standards, and the involvement of non-governmental organisations (Lalonde 2010). In Nigeria as in many other countries, the primary and main regulator of PSCs is the state. The regulatory policy adopted by the state, prohibited activities, offenses, and penalties, as well as the performance of the regulatory authority are the subject of the following sub-sections.

\section{Regulatory Policy for PSCs in Nigeria}

The PGC Act No. 23 of 1986 amended as the PGC Act, Chapter P30, Law of the Federation of Nigeria in 2004 is the main law which provides for the licensing and control of PSCs in Nigeria. The Act provides for the establishment of a regulatory authority for PSCs in the country. The Nigerian Security and Civil Defence Corps NSCDC Act 2003 and its amendment of 2007 complement the PGCs Act. Other laws that supplement the PGC Act include Labour Laws, the Nigerian Penal Code, the Criminal Code, and the Firearms (special provisions) Act (Cap. C38. Cap. F28. Cap. E18. Cap. R11.).

Section 1 (I) of the PGC Act conceptualizes the role of PGCs as that of performing the service of watching, guarding, patrolling, or carrying of money for the purpose of providing protection against crime. It stipulates that any organisation which seeks to perform such functions must not only be registered as a company under or pursuant to the Companies and Allied Matters Act (Cap. C20.), but must have obtained licence from the Minister of Interior in 
accordance with the provisions of the Act. License to operate private security business may be granted to applicants only when the regulatory authority is satisfied with the character, competence, and integrity of the directors or other persons in charge of operation of the company concerned as well as satisfied that the grant is justified having regard to national security and the public interest [PGC Act 1986, 2 (2a), and 3]. Similar considerations apply (at least in principle) in the case of employees to be approved for work in private security companies.

Furthermore, the PGC Act is clear that a licence may be suspended or revoked by the Ministry at any time if satisfied that the company holding the licence is unsuitable to continue to hold such licence [Section 4(4)]. With regard to control and administration of PSCs, the Act provides that every company shall keep complete records of its activities including all persons employed from time to time in carrying on the business of the company and make such records available to the regulatory authority whenever requested by the Ministry for inspection. Also, it prohibits PSCs and their personnel from bearing firearms or ammunition in the course of their duties and insists that the training syllabus and instructions of PSCs must be approved for use by the Minister. An examination of prohibited activities, offences, and penalties contained in the private security policy in Nigeria sheds further light on the system of regulation on the ground.

\section{Prohibited Activities, Offences, and Penalties}

The PGC Act further spells out all prohibited activities, offences, and penalties to guide PSCs in Nigeria. Such activities include PSCs acting as debt collectors, police officers, or "private detectives". The expression "private detective" is prohibited for PSCs in Nigeria. It is also wrong for PSCs to divulge to outsiders any information acquired in the course of their duties. This is one aspect of public and state security that is gaining increasing attention-the privacy of information, including who collects the personal information of others, how it is stored, shared, and access to it is controlled (Lalonde 2010). As Lalonde observes, in the course of their duties, civilian private security companies and operatives often legitimately collect information on private individuals, companies, and government. If specific regulations such as the one under consideration are lacking, and, if the private security company is a multinational, the information could be stored offshore.

Offences stipulated in the PGC Act include provision of false information for the purpose of securing approval; acting as employee of any company that has not been licenced; failure to carry identity card while on duty; wearing, carrying, or bearing any article that is prohibited; bearing or possessing firearms or ammunition; advertising business without specifying address; selling or disposing company's licence; unlawful entry; misrepresentation; and the exercise of special powers not entitled to by PSC personnel. Arguably, some of these provisions of the law, particularly the prohibition on the use of arms or ammunitions are controversial considering the nature of threats (e.g. armed robbers and terrorists) that private security guards are hired to safeguard against in some context. As revealed in an interview with CEOs, the prohibition on arms is regarded by stakeholders in the industry as the greatest weakness of the law on PGCs (interviews with CEOs, Abuja, February 2015).

Major penalties for violating the provisions of the PGC Act include, a fine of 400 or imprisonment for 12 months or both in the case of individuals and a fine of not less than $\$ 5,000$ in the case of a body (whether corporate or incorporate) [Section 32(1) (a) (b)]. Again, this is one area where some stakeholders felt the law is inadequate because the penalties in their view are not sufficient to deter potential defaulters (interviews with CEOs, Abuja, February 2015). However, when an offence relates to the possession of firearms, the offender shall be punished as prescribed 
under the Firearms Act or any other relevant enactment (Cap. F28.). Finally, as pointed out earlier, the Minister may revoke the licence of any company or any approval given in respect of an employee of a company under the provisions of the Act where such company or person contravenes any of the provisions of the Act (Section 34).

\section{Regulatory Authority for Private Security Companies: Role and Function Performance}

In accordance with the provision of Section 9(1) of the PGC Act which states that "there shall, for the purpose of this Act, be a licensing authority for private guard companies, who shall be an officer in the Ministry for which the Minister has responsibility, or such public officer as may be designated in that behalf by the Minister", the Nigerian parliament, in May 2003, passed an Act-the Nigeria Security and Civil Defence Corps (NSCDC) Act, which recognises the NSCDC as the "licensing authority" for PSCs in the country (NSCDC Act 2003).

Prior to 2003, PSCs were directly supervised by the Ministry of Internal Affairs, now Ministry of Interior (interview with an officer of the NSCDC FCT Command, Abuja, January 28, 2015). The NSCDC Act 2003 mandates every PGC wishing to be registered to have a minimum share capital of 10 million naira ( 10 million). In May 2007, the 2003 Act was amended in order to enhance the capacity of the NSCDC to provide protection, crises resolution, and security to public infrastructures and related matters. The amendment of Section 3(1) of the Principal Act provides that the Corps shall recommend to the Minister the registration of private guard companies; from time to time, inspect the premises of private guard companies, their training facilities and approve same if it is up to standard; supervise and monitor the activities of all private guard companies and keep a register for that purpose; periodically organise workshop and training courses for private guard companies, and seal up any private guard company which operates without a valid licence [NSCDC (Amendment) Act 2007].

Interviews with the agency revealed that the NSCDC has designated a special department-the private guard companies (PGC) department for effective performance of these roles. The department performs many duties including the following: licencing of qualified PGCs; monitoring and supervision of PSCs' activities; supervision of recruitments, training, and inspection of training facilities of private guard outfits; upgrading of licences from category $\mathrm{B}$ to $\mathrm{A}$; annual renewal of operating licence of PGCs; sealing of illegal PSCs; seeing to the welfare of their guards; breeding and training of guard dogs; and inspection of PGC office facilities and their environment (interview with an officer of the PGC department of the NSCDC FCT Command, Abuja, January 28, 2015).

In discharging these duties, the department is largely guided by provisions of the PGC and the NSCDC Acts. This is why before issuing licence to applicants, the department ensures that in addition to registration with the corporate affairs commission (CAC) and having a share capital of not less than $\$ 10$ million, one of the directors of the company is a retired military or paramilitary personnel from the rank of major or commissioner respectively. It also ensures that no foreigner is allowed to be part of the directors.

Furthermore, there are two categories of licences that can be issued to intending PSC operators depending on the operational capacity of the applicants. These are: category "A" and category "B". Category " $A$ " licence is issued to companies that intend to employ up to 500 security guards or more while category " $\mathrm{B}$ " is for those that will employ less. The two types of operational licenses are also differentiated by their costs which have recently been reviewed upward. The fee for category "B" licence for instance increased from $\$ 800,000$ to 2 million, while category " $A$ " licence now costs 3 million 
from 11 million. Furthermore, relocation of head office formally costs $\$ 5,000$ but has now significantly increased to 100,000. Cost of additional director's form was $\$ 7,500$ but slightly increased to $\$ 10,000$. Similarly, the fee charged for a certified true copy of the licence for category "A" increased from $\$ 100,000$ to $\$ 150,000$, while that of category "B" moved up to $\$ 100,000$ from $\$ 50,000$. Cost of renewing a licence has increased from 100,000 and $\$ 75,000$ to $\$ 200,000$ and $\$ 150,000$ respectively for category “A" and "B". Finally, interstate branch fee has moved up to $\$ 30,000$ from \#20,000 (interview with an officer of the PGC department of NSCDC FCT Command, Abuja, January 28, 2015).

In order to assess the performance of the regulatory authority, it is important to analyze its annual performance report for certain specified period of time. To this end, the author summarizes and presents the annual performance report of the PGC department of the NSCDC for the period 2006-2012 in Table 1. The table indicates that the most frequently performed regulatory function of the NSCDC was renewal of licences (S/No. 6). This is perhaps so because the PSCs are required by law to renew their licence every year.

On the other hand, the relatively high number (735) of companies sealed within the period may be interpreted as the direct result of the proliferation of non-licensed (800) PSCs in the country. It also suggests that sealing an illegal company is the major weapon in the hand of the agency for ensuring compliance with the provisions of the PGC Act with regard to licensing. Companies that are registered but not licensed as well as those that are unable to renew their licenses as at when it is due are liable to be sealed. It should be expected that many of the sealed companies, especially those that had obtained the licence and were already pulling good customers would do whatever is necessary (e.g. renew their license) to get back to business. Consequently, it is logical that every year some (e.g. 120 in year 2006) companies were reopened by the NSCDC.

Another interesting revelation from the performance report of the agency is the fact that every year at least one company is upgraded from category " $\mathrm{B}$ " to " $\mathrm{A}$ " and there are instances in which some category "A" companies were downgraded to " $\mathrm{B}$ ”, but this was fewer (6 compared to 14). This is informative on the rate of growth in the market for private security and in particular, how it influences the number of employees per private security company. PGCs with category "B" licence are expected to request for upgrading once they noticed that the number of private security guards in their employment has exceeded the maximum limit of 499. The same applies to companies with category "A" license that may wish to downgrade to " $\mathrm{B}$ " as a result of unfavourable circumstances surrounding their businesses (interview with an officer, NSCDC FCT Command, Abuja, January 28, 2015). Finally, it is interesting to note that the agency also organises stakeholder's forum for operators of PSCs in the country at least once in every year except in 2009 and 2011. Such forums are often important avenues for members to arrive at a consensus on certain industry standards that would benefit all stakeholders.

Part of the operational strategy of the PGC department of the NSCDC in discharging its roles is the creation of an operational unit which with the assistance of the surveillance unit goes round to monitor the companies and assess their offices and training facilities. There is also an intelligence unit whose staff sometimes disguise as applicants to know the content of training of the PSCs (interview with an officer, NSCDC FCT Command, Abuja, January 28, 2015). Furthermore, at the beginning of every year, the NSCDC through the relevant department usually asked all the PSCs to furnish it with information on their training and recruitment so as to track it. "Most of the PSCs have their training facilities, instructors and teachers but cannot train the recruits without the 
Table 1. Summary of NSCDC (PGC) Performance Report (2006-2012)

\begin{tabular}{llllllllll}
\hline \multirow{2}{*}{ S/N } & Function performed & \multicolumn{9}{c}{ Year (2006-2012) } \\
\cline { 3 - 10 } & & 2006 & 2007 & 2008 & 2009 & 2010 & 2011 & 2012 & Total \\
\hline 1. & No. of PGCs granted license & 22 & 59 & 44 & 19 & 60 & 72 & 130 & 406 \\
2. & No. of PGCs awaiting license & 92 & 157 & 195 & 221 & 43 & - & 92 & 800 \\
3. & No. of PGCs sealed & 206 & 100 & 43 & 30 & 78 & 140 & 138 & 735 \\
4. & No. of PGCs reopened & 120 & 48 & 10 & 10 & 10 & 110 & 27 & 335 \\
5. & No. of PGCs licenses revoked & - & 2 & - & - & - & - & - & 2 \\
6. & No. of licenses renewed & 145 & 170 & 150 & 135 & 218 & 580 & 349 & 1,747 \\
7. & No. of PGCs upgraded & 2 & 4 & 4 & 2 & 1 & 1 & 2 & 14 \\
8. & No. of PGCs downgraded & - & 1 & 1 & - & 2 & - & 2 & 6 \\
9 & PGC stakeholders' forum & 1 & 1 & 1 & - & 1 & - & 1 & 5 \\
10 & No. of PGCs prosecuted & - & - & - & - & - & - & 4 & 4 \\
\hline
\end{tabular}

Note. Source: NSCDC (PGC) Annual Performance Report (2006-2012).

consent of the NSCDC” (interview with an officer, NSCDC FCT Command, January 28, 2015).

The interviews further revealed that the major penalty which often applies on defaulters, especially on illegal operators, is sealing the company's office. This corroborates the findings from the annual performance report of the agency discussed above. According to the interviewee, there is lack of adequate penalties attached to some of the offenses provided in the PGC Act which tend to "make the agency appear like a toothless bull dog", adding that "a new Act is at the national assembly for consideration and by the time it is approved, it will take care of the problem of inadequate penalties" (interview with an officer, NSCDC FCT Command, January 28, 2015).

In addition, the interview sheds more light on what it means for the PGC department to see to the welfare of the guards as one of its primary duties. One of the ways this is achieved is by advising the PGCs on the need to set standards on fees from clients. According to the interviewee, "there is association of PGCs and we advise them to fix price for their services by themselves as there is currently no uniform salary in the sector". In addition to this, the agency has "an alternative dispute resolution (ADR) department which resolves all disputes between guards and their employees" (interview with an officer, NSCDC FCT
Command, Abuja, January 28, 2015). Regarding the duty to breed and train guard dogs, the agency has a special unit made up of vets that breeds and trains security guard dogs. Finally, with regard to inspection of PGC office facilities and their environment, the interviewee noted that the NSCDC normally inspect PGCs facilities and environments periodically to ensure they are in tune with global standards.

\section{DISCUSSION}

The foregoing analysis of the current regulatory set up for PSCs in Nigeria has shown that the PGC Act of 1986 remained the main law through which PSCs are regulated in the country. It has also demonstrated how in addition to its primary function of providing protection, crises resolution, security to public infrastructures, and related matters, the NSCDC doubled as the licensing authority for PSCs in the country. In this section, the author discusses the regulatory issues arising from the Nigerian system of regulation as analyzed in the light of global best practices in the private security industry.

From the analysis of the regulatory policy for PSCs in Nigeria presented above, it is clear that emphasis is on licensing of the corporate body that engages in the security business to the neglect of the 
private security guards whose conducts have implications for citizen security. The policy is clearly based on federal regulation and the system does not promote specialization within the private security industry. In comparison to what obtains in developed countries such as the USA (where licensure and regulation may vary from state to state) and the UK (where the industry is divided into different sectors for effective regulation) or even to South Africa (where the standards of professionalism and effectiveness are only comparable to the levels found in the developed world), the regulatory system in Nigeria leaves much to be desired (Strom et al. 2010; Chidi 2012; Madu and Okereke 2016).

In the USA, as an example of state regulation, licensure is available for private security firms and organisations who hire private detectives, private security contractors, and private alarm contractors (Strom et al. 2010: 6-1). States such as Florida even have licensure for repossession activity, school security guards, the carrying and use of firearms, and security managers (Nemeth 2004 cited in Strom et al. 2010: 1-6). In the UK, individuals must apply for a security licence in order to perform designated activities within the private security industry and compulsory training for individual operatives exists alongside mandatory criminal records and identity checks during licence application (Madu and Okereke 2016). According to Lalonde (2010), the United Arab Emirates was in the process of creating federally regulated training standards for specialty classifications of civilian security guard licenses, including bank security, hotels, airports, and hospitals. In Nigeria, the case is different. Once a company obtains the license to operate a PGC, it is qualified to offer any of the components of private security services available or as may be required by its clients. Furthermore, although the PGC Act insists that the training syllabus and instructions of PSCs must be approved for use by the Minister, this does not amount to the existence of a national standard for the training of private security guards in the country. As a consequence, the duration, content, and trainers of new recruits in the industry are left to the discretion and capability of the various PSCs.

Apart from the limited regulatory scope which focused solely on companies, the lack of specialty classification within the private security industry in Nigeria, and the lack of national standard for the training of security guards in the country, there are also concerns about the effectiveness of the regulatory authority in monitoring and supervising the PSCs to ensure compliance which is why many companies still operate without licence (Madu and Okereke 2016). It is also the reason why contracts are frequently won and lost by undercutting competitor's bids which made it difficult to improve on overall standards and procedures as well as higher quality service (Chidi 2012). Also, the very presence of foreign PSCs constitutes a violation of the PGC Act which stipulates that all PSCs must be completely owned by Nigerians (Kwaja 2014). On the other hand, exclusion of foreign participation in the Nigerian private security industry is seen by some as a challenge as it amounts to a restriction on trade in services and a breach of liberal economic principles (Madu and Okereke 2016).

Another policy issue arising from the regulation of PSCs in Nigeria is this: The cost and conditions for obtaining operational licence are expensive and difficult for low and middle income earners to afford. Small businesses that may have the expertise to provide specialized security services are finding it difficult to enter the industry due to the cost, while those already in business are finding it difficult to break even due to increased cost of operation. In the author's interview with PSC CEOs on their perception of the cost of registering a PSC in Nigeria, nearly all (93.3\%) the respondents think that the cost of registration was very high (61.3\%) or high (32\%). This is not good for the system. As Madu and Okereke (2016) observed, the additional overheads from 
licensing costs are most likely responsible for the low personnel wages across the industry. In addition to cost, the condition on share capital, membership of the board of directors, and citizenship has also complicated the process of licensing which is increasing the tendency to operate illegally.

Finally, the various industry associations are supposed to complement the effort of the government in ensuring adherence to global standards in the industry for sustainable quality service delivery but they are busy pursuing their own separate agenda (Abrahamsen and Williams 2005). All these challenges meshed together to render the current state-centred regulatory setup in Nigeria ineffective and unsustainable. As Scheye (2009) argued, if the capacity of the state to regulate its own activities is weak, then it is even weaker with regard to regulating the private security sector.

\section{CONCLUSIONS}

In summary, this paper has shown that private security companies through the services they provide complement the police in crime prevention, order maintenance, and general improvement of security and safety in societies. But in order to fully benefit from their contribution and prevent them from engaging in illegal activities, societies have policy on how they should be regulated. The analysis and discussion of how the Nigerian state regulates the activities of PGCs presented above revealed that the system is characterized by a lack of specialty classification of private security licenses, limited regulatory scope with a focus on licensing of companies to the neglect of individual security guards, lack of uniform provision on training, weak regulatory authority, and high cost/difficult conditions for obtaining operational license. On the basis of these findings, it is the conclusion of the paper that the current regulatory setup for PSCs in Nigeria is ineffective and unsustainable. Not only does the policy fail to make security accessible and affordable to low and middle income earners but the state-centeredness of the system does not allow for adequate utilization of the benefits to be derived from non-state regulations. To address the challenges associated with the existing system of state regulation and promote equitable policing in Nigeria, the following recommendations are hereby proffered:

The Nigerian government in consultation with relevant stakeholders in the private security industry should urgently review the legal framework for PSCs particularly the PGC Act of 1986 and align its provisions with global standards and practices in the private security industry. Also, other relevant laws on PSCs (such as relevant sections of the NSCDC Acts and labour laws) should be harmonized with the PGC Act into one single document through the regulatory authority for easier reference. The amendments should include the following:

Provision for specialty classification of PGCs' licenses in the country so that the PSCs can specialize on one or two (e.g. guard and patrol, armoured car services, executive protection, guard dog services, etc.) of the many components of private security instead of the current tendency by most of them to be "jack of all trade and master of none".

Provide the licensing and adequate regulation of behaviours of the individuals employed as private security guards in the country in order to raise the standard of competence and professionalism across the industry. The regulatory authority should be stringent in the screening of applicants before issuing them the licence to operate. The screening method should include a combination of background checks, polygraph examinations, checks of criminal records, drug tests, and relevant licence-linked training qualifications. The same procedure should be applied by the PSCs when considering an applicant for employment.

Provide a uniform standard of mandatory training for the entry-level staff of private security companies 
and standardized specialized trainings for the employees in line with the various components of private security before deployment to their place of primary assignment. The Act should specify the minimum length (at least two months) and content (e.g. lessons on clients' style of living, poise and quick thinking, and a personal protection) of training to be given by all PSCs.

The various industry associations in the country including the Nigerian Chapter of the American Society for Industrial Security (ASIS), National Professional Security Association (NPSA), the Society of Security Practitioners of Nigeria (SSPN), the Security and Safety Association of Nigeria (SSAN), and the Association of Licensed Private Security Practitioners in Nigeria (ALPSPN) should as a matter of urgency stop pursuing their own separate agendas and be united in checkmating the unprofessional activities of unlicensed/substandard security companies and improve standards in the private security industry. The associations should sustain the call for tighter regulation, imposition for sector wide standards for training and minimum wage as well as the need for cooperation among PSC operators since lack of these has made it difficult to improve overall standards, procedures, and higher quality service.

To sustain and improve the level of effectiveness of the NSCDC, government should strengthen the capacity of the PGC department of the agency by providing it with the required resources especially modern technological equipment and logistical materials for monitoring and supervising the PSCs. Adequate training should be provided for the personnel of the department to make them more disciplined and professional in their dealings with PSCs and to avoid corrupt tendencies while discharging their functions. The department should more frequently inspect what they expect from PSCs premises and facilities and their monitoring activity should also cover the conduct of private security officers.

If government cannot support PSCs with certain incentives to ease the cost of operating a PSC in Nigeria, it should at least reduce the cost of registration and licensing and rather lay emphasis on experience and commitment of applicants to contribute to security in the country.

If these recommendations are implemented, it will make regulation of private security companies in Nigeria more effective. However, for the policy on PSCs to be sustainable and promote equitable policing, it should not only be based on the reduction or absence of crime for those that can afford the PSCs services, but rather the absence of structures that perpetuate inequality, poverty, and unemployment. Lasting peace and security should be at the base of the drive to sustainable development. This can only come about in a more equitable, egalitarian, just, and economically buoyant society where those that work hard have everything they need.

\section{References}

Abrahamsen, R. and M. Williams. 2005. The Globalization of Private Security Country Report: Nigeria. Aberystwyth: University of Wales.

—. 2009. "Security Beyond the State: Global Security Assemblages in International Politics.” International Political Sociology 3(1):1-17.

Alemika, E. E. O. 1993. "Criminology, Criminal Justice and Philosophy of Policing.” In Policing Nigeria: Past, Present and Future, edited by T. N. Tamuno, I. L. Bashir, E. E. O. Alemika, and A. Akano. Lagos: Malthouse Press Ltd.

Alemika, E. E. O. and I. Chukwuma. 2004. The Poor and Informal Policing in Nigeria. Lagos: CLEEN Foundation.

Baker, B. 2002. "Living With Non-state Policing in South Africa: The Issues and Dilemmas.” The Journal of Modern African Studies 40(1):29-53.

Bassey, C. O. and C. Q. Dokubo, eds. 2011. Defence Policy of Nigeria: Capability and Context, a Reader. Bloomington: Authorhouse.

Bayley, D. H. and C. D. Shearing. 2001. The New Structure of Policing: Description, Conceptualization and Research Agenda. Washington D.C.: National Institute of Justice, Department of Justice.

Bearpark, A. and S. Schulz. 2007. "The Private Security 
Challenge in Africa: Problems and Options for Regulation.” Pp. 73-88 in Private Security in Africa: Manifestation, Challenges and Regulation, edited by S. Gumedze. ISS Monograph Series No. 139. Pretoria: Institute for Security Studies.

Berg, J. 2010. "Seeing Like Private Security: Evolving Mentalities of Public Space Protection in South Africa." Criminology and Criminal Justice 10(3):287-301.

Berg, J. and J. Nouveau. 2011. "Towards a Third Phase of Regulation: Re-imagining Private Security in South Africa.” South African Quarterly 38:23-32.

Chidi, E. E. 2012. "The Role of Nigeria Security and Civil Defence Corps in the Regulation and Management of Private Security Companies in Nigeria: Issues and Challenges.” A research project submitted to the National Institute for Policy and Strategic Studies, NIPSS, Kuru.

Chukwuma, I. 2005. "Improving Police-Community Relations in Nigeria: Issues at Stake.” Presented at the Workshop on Prevention of Violation of Human Rights in Nigeria, organized by the Nigeria Police Force at Sheraton Hotels and Towers, Abuja, August 18-19, 2005.

Crawford, A. 2006. "Networked Governance and the Post-regulatory State? Steering, Rowing and Anchoring the Provision of Policing and Security." Theoretical Criminology 10(4):449-479.

Cunningham, W. C. and T. H. Taylor. 1985. The Hallcrest Report: Private Security and Police in America. Portland, Oreg.: Chancellor.

Foucault, M. 1988. “Technologies of the Self.” In Technologies of the Self: A Seminar With Michel Foucault, edited by L. H. Martin, H. Gutman, and P. H. Hutton. London: Tavistock Publication.

Gill, P. 2002. "Policing and Regulation: What Is the Difference?” Social and Legal Studies 11(4):523-546.

Gumedze, S. 2007. "Regulating the Private Security Sector in South Africa.” Social Justice 34(3/4):195-207.

Isima, J. 2007. "Regulating the Private Security Sector: An Imperative for Security Sector Governance in Africa." Journal of Security Sector Management 5(1):1-16.

Johnston, L. and C. Shearing. 2003. Governing Security: Explorations in Policing and Justice. London: Routledge.

Jung, D. 2009. "Security: Some Critical Observations About Concepts and Policies.” In African Security Governance: Emerging Issues, edited by G. Cawthra. Johannesburg: Wits University Press.

Kakalik, J. S. and S. Wildhorn. 1972. Private Security in the United States. Vol. 5. Washington, D.C.: US Department of Justice.

Kwaja, C. M. 2011. The Triumph of Liberalism in Nigerian Security Provision. Retrieved November 8, 2011 (http://thinkafricapress.com/nigeria/triumph-liberalism-nige rian-security-provision).

- 2014. "Private Military/Security Companies, Privatisation of Violence and National Security: Implications for Democratic Governance in Nigeria.” Working Paper, Centre for Democracy and Development, Abuja.

Lalonde, M. 2010. “Civilian Private Security Services: Their Role, Oversight and Contributions to Crime Prevention and Community Safety.” Background paper for the Planning Meeting (May 10-11, 2010) of the United Nations Office on Drugs and Crime.

Madu, B. 2016. Private Security as a Driver for Economic Growth. Retrieved September 22, 2016 (http://www. vanguardngr.com/2016/05/private-security-driver-economic -growth/).

Madu, B. and D. Okereke. 2016. Proposal for Independent Regulatory Authority for Nigeria's Private Security Industry. Retrieved September 22, 2016 (http://donokereke.blogspot. com.ng/2016/04/proposal-for-independent-regulatory.html).

Marenin, O. 1985. "Policing Nigeria: Control and Autonomy in the Exercise of Coercion." African Studies Review 28(1):73-93.

Molomo, M. G. 2009. "The Link Between Sustainable Development and Security in Botswana.” In African Security Governance: Emerging Issues, edited by G. Cawthra. Johannesburg: Wits University Press.

Odekunle, F. 2010. “Internal Security and Development.” In Police, Security and Democratic Governance in Nigeria, edited by E. E. O. Alemika, M. Haruna, and B. Yusuf. Ibadan: Spectrum Books Ltd.

Osborne, D. and T. Gaebler. 1992. Rethinking Government. Harmondsworth: Penguin.

Owusu, G., A. Owusu, M. Oteng-Ababio, C. Wrigley-Asante, and I. Agyapong. 2016. “An Assessment of Households' Perceptions of Private Security Companies and Crime in Urban Ghana.” Crime Science Journal. Retrieved July 20, 2016 (http://crimesciencejournal.springeropen.com/articles/ 10.1186/s40163-016-0053-x).

Ritzer, G. 1996. Sociological Theory. 4th ed. New York: McGraw-Hill.

Ritzer, G., ed. 2005. Encyclopaedia of Social Theory. Vol. II. London: Sage.

Scheye, E. 2009. "State-Provided Service, Contracting out, and Non-state Networks: Justice and Security as Public and Private Goods and Services.” Discussion paper jointly commissioned by the International Network on Conflict and Fragility (INCAF) and the Partnership for Democratic Governance (PDG), OECD.

Schmalleger, F. 2009. Criminal Justice Today: An Introductory Text for the 21st Century. 10th ed. New Jersey: Prentice Halls. 
Schneier, B. 2006. Beyond Fear: Thinking Sensibly About Security in an Uncertain World. New York: Springer.

Shearing, C. D. 1992. "The Relation Between Public and Private Policing." Crime and Justice 15:399-434.

Shearing, C. D. and P. C. Stenning. 1981. "Modern Private Security: Its Growth and Implications.” Pp. 193-245 in Crime and Justice: An Annual Review of Research, edited by M. Tonry and N. Morris. Chicago: University of Chicago Press.

Strom, K., M. Berzofsky, B. Shook-Sa, K. Barrick, C. Daye, N. Horstmann, and S. Kinsey. 2010. "The Private Security Industry: A Review of the Definitions, Available Data Sources, and Paths Moving Forward.” A research report submitted to the U.S. Department of Justice.

The Nigerian Security \& Civil Defence Corps (NSCDC) Act, 2 (2003) and the Amendment Act (2007), Laws of the Federation of Nigeria.
The Private Guard Companies Act (1986), Cap 367 Laws of the Federal Republic of Nigeria.

The World Bank. 2011. World Development Report 2011: Conflict, Security and Development. Washington, D.C.: The World Bank.

\section{Bio}

Plangshak Musa Suchi, Ph.D. in Sociology (with specialization in Criminology) from the University of Jos, lecturer in the Department of Sociology, Bingham University, Karu, Nasarawa State, Nigeria; research fields: criminal violence, non-state policing in Africa, regulatory institutions and private policing in Africa, private security companies and policing in Nigeria, disposition of criminal cases in Nigerian lower courts, cybercriminal victimization and cyber security. 